\title{
Endemic species predation by the introduced smooth-billed ani in Galápagos
}

\author{
Sophia C. Cooke (D) David Anchundia • Emma Caton • Lucy E. Haskell • \\ Heinke Jäger · Yatindra Kalki · Óscar Mollá · Jacqueline Rodríguez • \\ Tristan D. Schramer $\cdot$ Anna Walentowitz $\cdot$ Birgit Fessl
}

Received: 28 May 2019/Accepted: 21 March 2020/Published online: 31 March 2020

(C) The Author(s) 2020

\begin{abstract}
The introduced smooth-billed ani Crotophaga ani has become widespread across the Galápagos archipelago in the past half-century. It is known to predate upon a range of native and endemic species, and is a potential vector for the spread of invasive plants and parasites. Here we report previously undocumented examples of smooth-billed ani predation in Galápagos, including that of an endemic racer snake and a scorpion. We highlight the possibility of smooth-billed anis having a serious impact on
\end{abstract}

Electronic supplementary material The online version of this article (https://doi.org/10.1007/s10530-020-02251-3) contains supplementary material, which is available to authorized users.

S. C. Cooke $(\bowtie)$

Department of Zoology, University of Cambridge, The David Attenborough Building, Pembroke Street, Cambridge CB2 3QZ, UK

e-mail: sophia.cooke@cantab.net

D. Anchundia $\cdot$ H. Jäger $\cdot$ J. Rodríguez $\cdot$ B. Fessl Charles Darwin Research Station, Charles Darwin Foundation, Santa Cruz, Galápagos, Ecuador

E. Caton

Durrell Wildlife Conservation Trust, La Profonde Rue, Trinity, Jersey, Channel Islands JE3 5BP, UK

L. E. Haskell

Aigas Field Centre, Beauly, Inverness-shire IV4 7AD, UK the endemic Galápagos carpenter bee, a major pollinator, as well as native and endemic Lepidopterans and other invertebrates. In addition, we report smoothbilled ani predation of other introduced species and note the importance of further research on the widescale impacts of smooth-billed anis in Galápagos and their role within the archipelago's ecological networks.

Keywords Invasive species - Alien bird species . Island invasions · Impacts of introduced species . Endemic species

\footnotetext{
Y. Kalki · T. D. Schramer

Illinois Natural History Survey, Prairie Research Institute, Champaign, IL 61820, USA

Ó. Mollá

Escuela Superior Politécnica de Chimborazo, Riobamba, Ecuador
A. Walentowitz
Department of Biogeography, University of Bayreuth, Universitätsstraße 30, 95448 Bayreuth, Germany 


\section{Introduction}

The smooth-billed ani Crotophaga ani (hereafter ani) is thought to have been introduced to Galápagos in the 1960s, from its native range of continental South America (Cooke et al. 2019). This was reportedly done by farmers, in the hope that the birds would predate upon the ticks that plagued their cattle stocks (Cooke et al. 2019). This cuckoo has since spread to almost all islands in the archipelago and has reached an estimated population of 250,000 (Connett et al. 2016). Although repeated small-scale attempts have been made to control the species, no official plan for further control or eradication is currently in place.

Introduced species are considered a major environmental problem for Galápagos (Izurieta et al. 2018). Anis are thought to be having a wide range of impacts on local ecosystems and native species. They are known to predate upon many endemic invertebrate species including the Galápagos field cricket Gryllus abditus (Connett et al. 2016), the Galápagos carpenter bee Xylocopa darwini (Sandler 1988a; Jara 1995; Connett et al. 2016; Cisneros-Heredia 2018) and the large painted locust Schistocerca melanocera (Rosenberg 1987; Connett et al. 2016). They have also been documented robbing the nests of Darwin's finches (Connett et al. 2016; Cooke et al. 2019) and are suspected of taking nestlings of other endemic bird species (Jara and de Vries 1995; Wiedenfeld 2005; Cooke et al. 2019). In addition, ani predation of endemic lava lizards (Microlophus spp.) has been reported multiple times (Sandler 1988b; Jara 1995; Tapia et al. 2000; Connett et al. 2016).

Anis are effective distributors of the invasive blackberry Rubus niveus (Soria Carvajal 2006; Guerrero and Tye 2011; Llerena 2012; Connett et al. 2016) and are known to feed on the fruits of several other introduced plant species, including the common guava Psidium guajava (Ballestros 1983), the multicoloured lantana Lantana camara (Guerrero and Tye 2011; Connett et al. 2016) and the currant tomato Solanum pimpinellifolium (Connett et al. 2016). They are also a known host of the invasive fly Philornis downsi (Fessl and Tebbich 2002; Causton et al. 2013), a parasite that causes high chick mortality in several native and endemic bird species (reviewed in Fessl et al. 2018).

Anis are, however, known to predate upon other introduced species as well. These include house mice Mus musculus (Connett et al. 2016), rats (specific species unknown; Sandler 1988b), and invertebrates including the yellow paper wasp Polistes versicolor (Jara 1995; Llerena 2012) and two species of cockroach, Periplaneta australasie and Pycnoscelis surinamensis (Jara 1995).

A recent review (Cooke et al. 2019) collated all accessible information on the possible impacts that anis are having in Galápagos. In doing so, the authors highlighted vast knowledge gaps concerning this introduced species, including a quantitative understanding of the impacts they are having via predation of native and endemic species, and recommended further research on their diet. It is of urgent necessity that our understanding of the interactions this species is having with native and other introduced species be improved, such that evidence-based decisions (Sutherland et al. 2004) can be made as to its priority for control or eradication. To this end, here we add to the knowledge outlined in the review and report on recently observed behaviours of, and predation by, anis in Galápagos.

\section{Methods}

\section{Dietary analysis}

During the period 2015 to 2017 inclusive, we caught 54 anis in mist nets and traps. We did this work in collaboration with the Galápagos National Park Directorate (GNPD), as part of a project to develop new and efficient methods of capturing anis (Cooke and Fessl in prep.). We undertook all netting and trapping in the lowland coastal area around Puerto Villamil on Isabela during three field seasons (April-May 2015; AprilMay 2016; January 2017). As anis are introduced, it was not appropriate for birds caught during these trials to be released. We therefore humanely euthanised the anis [using blunt force trauma to the head followed by cervical dislocation-both procedures are described in Leary et al. (2013)] and extracted their gizzards for content analysis.

During the same period, several anis were shot with air rifles by the GNPD in control trials in the highlands of Isabela and Santa Cruz. We accompanied the rangers on several occasions and collected a total of 64 ani bodies for gizzard content analysis. In addition, one ani body was collected that had been hit by a car, giving a total of 119 gizzards. 
We identified all possible vertebrate, invertebrate and plant material in the gizzards. In the 2015 samples from Santa Cruz only seeds of the invasive plant Rubus niveus were identified but in both 2016 and 2017 we attempted identification of all plant seeds. Seeds were classified as viable if they were intact and undamaged, and therefore thought to be able to germinate once they passed through the digestive system of the ani (Buddenhagen and Jewell 2006).

\section{Observations}

Whilst undertaking the research into methods of capturing anis, we noted any observations of ani interactions with other species. An additional observation of ani predation was recorded on San Cristóbal in November 2016 during fieldwork for another project.

\section{Results}

Dietary analysis

The gizzards of the anis that we analysed contained invertebrates (Table S1, Fig. 1), particularly of the orders Coleoptera, Lepidoptera and Hymenoptera, and plant seeds (Table S2, Fig. 2). The mean number of invertebrate specimens found in each gizzard was eight, with a maximum of 44 . The mean number of plant seeds was 71 , with a maximum of 1219 . Almost all plant seeds (80-100\% of the seeds of each species) appeared to be viable. We found several endemic and introduced species of both invertebrates and plants in the gizzards. All species of note are discussed below. Whilst analysing these contents we also found some small pieces of glass and plastic in one ani gizzard.

\section{Endemic species}

We found a total of 120 endemic Galápagos carpenter bees in 28 ani gizzards collected on Isabela. We also found thirty endemic large painted locusts in 14 gizzards from Isabela, 23 endemic huntsman spiders Olios galapagoensis in 14 gizzards from both Isabela and Santa Cruz, and one endemic mantis Galapagia solitaria in a gizzard from Santa Cruz. A large proportion of the anis' diet was made up of caterpillars, as well as some adult moths. We were not able to identify these species but as an estimated $80 \%$ of Lepidoptera species on Galápagos are not introduced (Roque-Álbelo and Landry 2018), it is likely that anis are feeding on several native and endemic moths and butterfly species. In addition, we found one scorpion in a gizzard collected in the lowlands of Isabela (Fig. 3). This is likely to be the endemic Hadruroides maculatus, the only species recorded on Isabela (Baert 2018).

We found seeds of 11 native plants in the gizzards collected on Isabela. The most common seeds we found in the samples collected in the highlands were Solanum americanum and Physalis pubescens, whilst in the lowland samples it was Tournefortia psilostachya and Vallesia glabra.

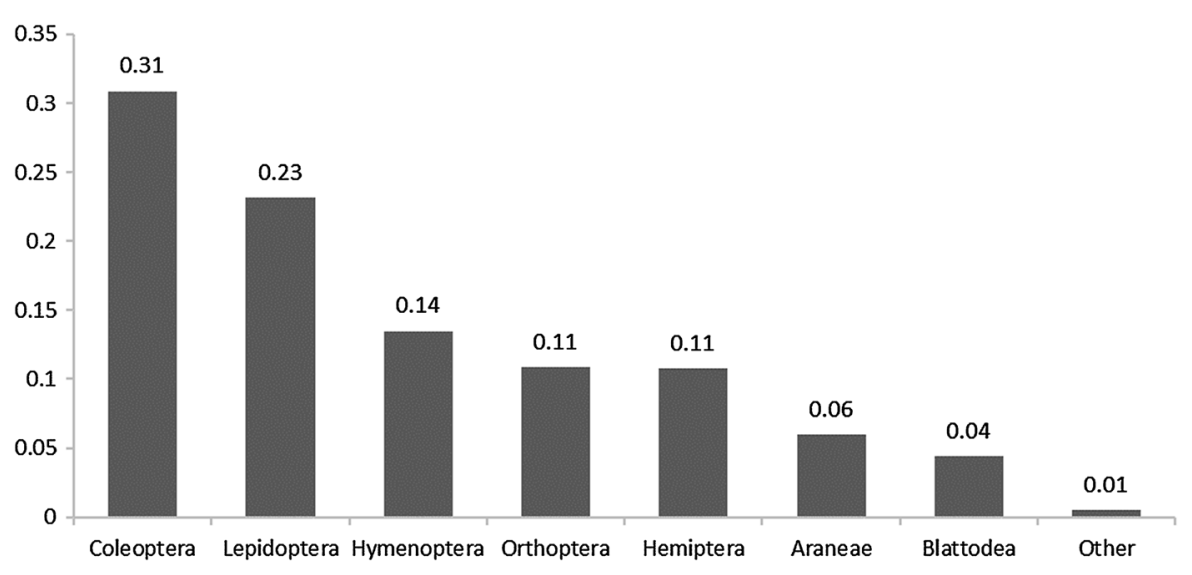

Fig. 1 Proportions of each invertebrate order found in all ani gizzards collected. "Other" encompasses the orders Diptera, Isopoda, Mantodea, Nematoda and Scorpionida, of which we identified one specimen of each 


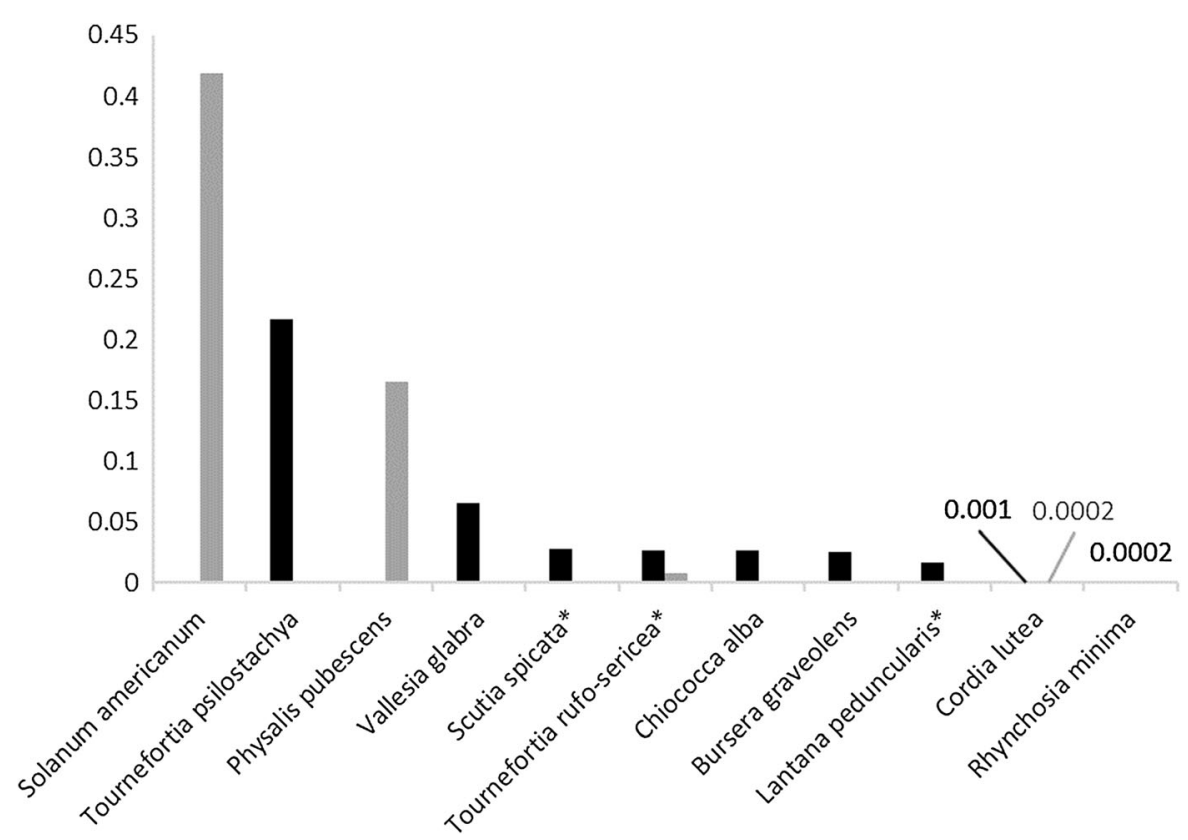

Fig. 2 Proportions of each seed type found in ani gizzards collected from Isabela. Those in grey were collected in the highlands in 2017 and those in black were collected from the lowlands in both 2016 and 2017. Endemic species are denoted by * on the x-axis label

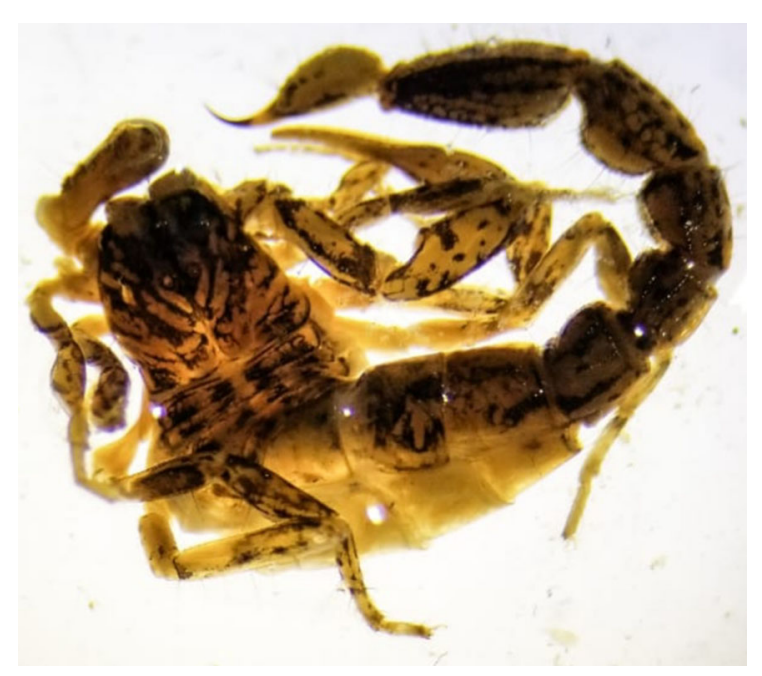

Fig. 3 A scorpion, identified as the endemic Hadruroides maculatus, removed from the gizzard of an ani collected on Isabela. Photographed by Jaqueline Rodriguez

\section{Introduced species}

We found two introduced Fowler's snouted treefrogs Scinax quinquefasciatus in separate ani gizzards, both of which were collected in the highlands of Santa Cruz. We also discovered one introduced gecko in an ani gizzard collected near the coast in Isabela. This was identified as Hemidactylus (T. Gamble pers. comm.) and is presumed to be the common house gecko Hemidactylus frenatus as this is the only Hemidactylus species recorded on the islands (Jiménez-Uzcátegui et al. 2017) and has previously been reported on Isabela (Torres-Carvajal and Tapia 2011). We found four yellow paper wasps in gizzards from both Isabela and Santa Cruz. Also in the gizzards from Isabela, we found nine introduced cockroaches (Order Blattodea), one introduced Pentatomidae (shield bug) of order Hemiptera, and one introduced ant (Odontomachus sp.).

In six gizzards collected in the highlands of Santa Cruz we found a total of 178 R. niveus seeds. None was found in the samples from Isabela. We did not find seeds from any other introduced plant species.

Observations

\section{Predation of an endemic Galápagos racer}

On 9 November 2016, we observed two anis on San Cristóbal, near the coast of the arid zone $\left(6092670.899828^{\circ} \mathrm{S}, 89.609267^{\circ} \mathrm{W}\right.$, WGS $84 ; 6 \mathrm{~m}$ elev). At the start of the observation, one ani was in the process of consuming a small (approximately $20 \mathrm{~cm}$ 
in length) eastern Galápagos racer Pseudalsophis biserialis (Zaher et al. 2018), an endemic species of snake (Fig. 4; HM 159659, HerpMapper 2019). The other ani was watching its conspecific but fled shortly after we arrived. Initially, the predating ani had the snake's head in its mouth, with most of the body outside of its bill. A struggle then ensued between the two, with the bird attempting to swallow the stillwriggling snake, before the snake eventually became less responsive. The ani swallowed most of it and then flew up into a nearby shrub to consume the rest.

\section{Predation of moths}

On multiple occasions, we observed anis feeding on moths at dawn at a sports stadium on Isabela (latitude -0.95122855 , longitude -90.971941$)$. There was a white wall present in this area which moths would frequently fly into in the low light of dawn, becoming temporarily stunned. A group of anis would wait

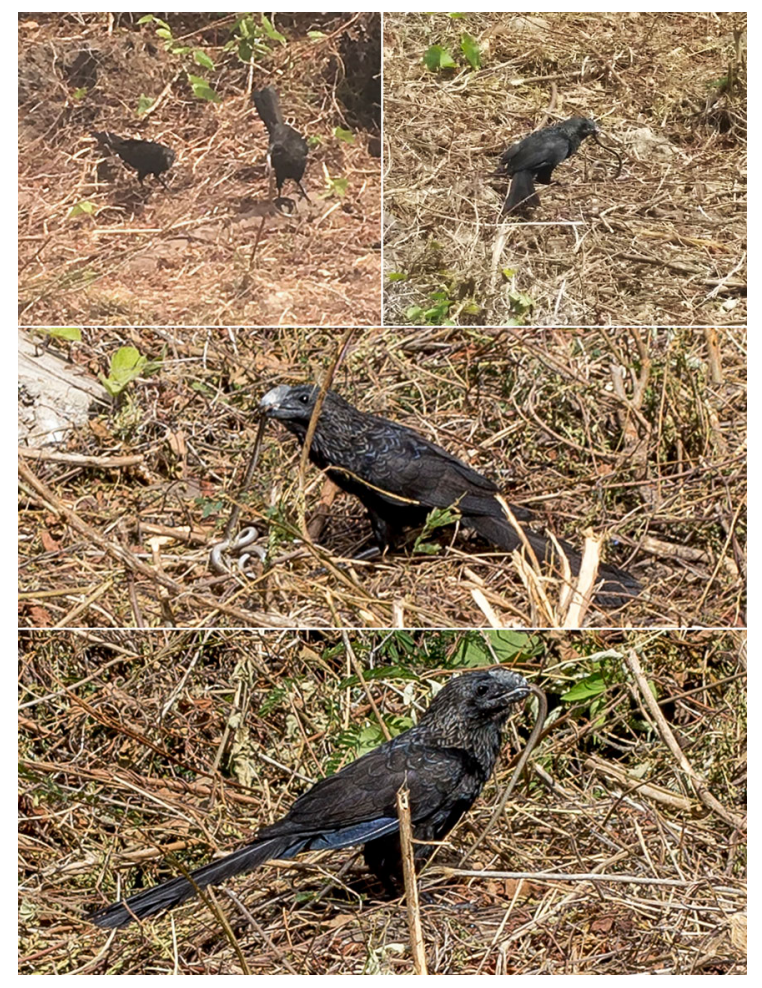

Fig. 4 Predation of an endemic eastern Galápagos racer Pseudalsophis biserialis by a smooth-billed ani. Observation recorded by Tristan D. Schramer and Yatindra Kalki, photographed by Ryan O'Reilly (top left), Celeste Walton (top right), and Favio Caraguay (middle and bottom) together at the bottom of the wall and jump up to catch these moths once they started arriving. We visited this site at other times of day but did not observe anis waiting by this wall other than at dawn. We were unable to identify most of the moths being caught by the anis, but we did observe predation of one endemic green hawkmoth Eumorpha labruscae. We observed anis predating upon moths in a similar way off the base of a street lamp in Santa Cruz in the early morning.

\section{Aggression between smooth-billed anis and endemic Galápagos mockingbirds}

We observed multiple altercations between anis and endemic Galápagos mockingbirds on Isabela in which one or two of each species would physically fight, whilst vocalising loudly. Other anis would often be present, watching these interactions but not joining in. We also noted that if ani calls were played during the trapping trials, mockingbirds would often fly rapidly into the area, calling loudly, as would Darwin's finches (various spp.) and other small passerines.

\section{Other observations}

On one occasion we observed ani predation of a Fowler's snouted treefrog during fieldwork and, on several occasions, we witnessed ani predation of yellow paper wasps. We were also informed that anis had been observed predating upon the introduced common house gecko around the town of Puerto Villamil on Isabela (local people pers. comm.) and we noted that this species, which we caught and humanely killed, was the preferred food of the captive lure anis we used in the trapping trials.

\section{Discussion}

Through dietary analysis and observation, we found evidence of predation by the introduced smooth-billed ani on a range of endemic, native and introduced species in Galápagos. Some of the predation we report has not been documented previously and so is an important addition to our knowledge of this species. Notably, we observed ani predation of an eastern Galápagos endemic racer snake and found a scorpion in one ani gizzard. We believe neither of these predation interactions have been recorded previously 
in Galápagos, nor have we found any record of ani predation of snakes or scorpions elsewhere.

We found large numbers of endemic carpenter bees in the gizzard samples collected (mean of 4.3 bees per bird captured on Isabela). The Galápagos carpenter bee is the only bee on the islands and is one of the most important pollinators, being responsible for a large proportion of the insect pollination in the archipelago (McMullen 1989; Chamorro et al. 2012; Traveset et al. 2013). Although ani predation of these bees has been recorded previously (Sandler 1988a; Jara 1995; Connett et al. 2016), the frequencies were lower, and this predation interaction has only recently been highlighted as a possible major impact of anis in Galápagos (Cisneros-Heredia 2018; Cooke et al. 2019). The solitary nature of this bee may render its population stability more vulnerable to the impacts of increased predation, and so the potential implications of anis for the Galápagos carpenter bee, and the species it pollinates, could be serious. We also found thirty large painted locusts [as previously reported by Rosenberg (1987) and Connett et al. (2016)], an endemic species whose conservation status and dietary importance for other bird species is currently unknown, as well as Lepidopterans, ani predation of which we also observed in the field. This predation upon Lepidopterans, which has also been documented previously (Rosenberg et al. 1990), is of concern due to the role of moths and butterflies as pollinators (Chamorro et al. 2012; Traveset et al. 2015) and as possible food for other bird species.

We observed several aggressive interactions between anis and endemic mockingbirds. These are not uncommon and there have been several previous reports, including incidents where mockingbirds have been killed by anis (Rosenberg 1987; Rosenberg et al. 1990; Jara and de Vries 1995; Tapia et al. 2000). Given the territoriality of both species during their breeding seasons, which are usually concurrent, this could be having a significant effect on the breeding success of the mockingbirds.

We found anis to be predating upon a range of introduced species, including Fowler's snouted treefrogs and common house geckos. We are not aware of previous documentation of these interactions, although anis are known to eat frogs in their native range (Young 1929; Koster 1971). Fowler's snouted treefrog is an established introduced amphibian species in Galápagos and is potentially impacting on native invertebrate populations via predation (Mieles and Bersosa 2005; Vintimilla 2005; Phillips et al. 2012; Cisneros-Heredia 2018). Introduced geckos are thought to compete with endemic species for habitat (Jiménez-Uzcátegui and Zabala-Albizua 2008; Y. Kalki and T. D. Schramer pers. obs.; D. F. CisnerosHeredia pers. comm.). Given that anis are willing to predate upon introduced geckos, it should be noted that it is likely they are taking endemic species as well. We also identified a small number of yellow paper wasps in the ani gizzards, which has been reported previously by Jara (1995) and Lasso (1997). These wasps are considered highly invasive (Causton et al. 2006), feeding predominantly on Lepidopteran larvae (Parent 2000).

It is unsurprising that we found $R$. niveus seeds in the gizzards collected in the highland areas. Anis have been shown previously to be effective distributors of this invasive species (Soria Carvajal 2006). However, they are also feeding on the seeds of several native and endemic plants, the latter including Tournefortia rufosericea, Lantana peduncularis and Scutia spicata. As anis are able to move over and between islands quite readily (Cooke et al. 2019), and the seeds we found mostly appeared to be viable, they may be assisting in the spread of these species. However, to verify this, germination experiments of seeds extracted from ani gizzards/faecal matter would be necessary.

Further research is urgently needed to establish the extent to which predation and competition by anis is affecting native and endemic vertebrates and invertebrates in Galápagos, particularly the endemic Galápagos carpenter bee. We recommend a wide-scale dietary analysis across multiple islands, habitats and seasons. In addition, a study of the impact of anis on breeding endemic mockingbirds would be beneficial. As a small number of the gizzards contained other introduced species, potential impacts on these populations should be considered as part of any wide-scale attempts of control or eradication of anis in Galápagos. Finally, it is unlikely that ingestion of glass and plastic material is limited to anis, and this could be an issue to investigate in other species in Galápagos.

Acknowledgements This study was part of the Galápagos Landbird Conservation Plan, jointly implemented by the Charles Darwin Foundation and the Galápagos National Park Directorate (GNPD) (permit numbers PC-09-15, PC-33-16, PC07-17). We thank the GNDP rangers for their assistance; Sandra Hervías and Surya Castillo for their help with seed 
identification; Pedro Ramón, Maricruz Jaramillo, Courtney Pike and Celina Leuba for their assistance in the field; and Tony Gamble for his help identifying the gecko specimen. In addition, we thank the Galápagos Conservation Trust who inadvertently part-funded one fieldwork season after S. C. Cooke won their "Galápagos Day" raffle in 2016. This study was supported by funding from the International Community Foundation (with a grant awarded by The Leona M. and Harry B. Helmsley Charitable Trust) as well as a grant from the Christ's College Cambridge Charles Darwin Research Fund. This publication is contribution number 2244 of the Charles Darwin Foundation for the Galápagos Islands.

Open Access This article is licensed under a Creative Commons Attribution 4.0 International License, which permits use, sharing, adaptation, distribution and reproduction in any medium or format, as long as you give appropriate credit to the original author(s) and the source, provide a link to the Creative Commons licence, and indicate if changes were made. The images or other third party material in this article are included in the article's Creative Commons licence, unless indicated otherwise in a credit line to the material. If material is not included in the article's Creative Commons licence and your intended use is not permitted by statutory regulation or exceeds the permitted use, you will need to obtain permission directly from the copyright holder. To view a copy of this licence, visit http://creativecommons.org/licenses/by/4.0/.

\section{References}

Baert LL (2018) CDF checklist of Galápagos arachnids-FCD Lista de especies de Aracnidos Galápagos. In: Bungartz F, Herrera H, Jaramillo P, Tirado N, Jiménez-Uzcátegui G, Ruiz D, Guézou A, Ziemmeck F (eds) Charles Darwin Foundation Galápagos Species Checklist-Lista de Especies de Galápagos de la Fundación Charles Darwin. Charles Darwin Foundation, Puerto Ayora, Galápagos: https://darwinfoundation.org/datazone/checklists/ terrestrial-invertebrates/arachnida/. Accessed 18 Jan 2018

Ballestros NA (1983) Los Garrapateros en la Parte Alta de la Isla Santa Cruz. Thesis, Colegio Nacional Galápagos

Buddenhagen C, Jewell KJ (2006) Invasive plant seed viability after processing by some endemic Galápagos birds. Ornitol Neotrop 17:73-80

Causton CE, Peck SB, Sinclair BJ, Roque-Albelo L, Hodgson CJ, Landry B (2006) Alien insects: threats and implications for conservation of Galápagos Islands. Ann Entomol Soc Am 99:121-143

Causton C, Cunninghame F, Tapia W (2013) Management of the avian parasite Philornis downsi in the Galápagos Islands: a collaborative and strategic action plan. Galápagos Rep 2011-2012:167-173

Chamorro S, Heleno R, Olesen JM, McMullen CK, Traveset A (2012) Pollination patterns and plant breeding systems in the Galápagos: a review. Ann Bot 110:1489-1501

Cisneros-Heredia DF (2018) The hitchhiker wave: non-native small terrestrial vertebrates in the Galápagos. In: de Torres
ML, Mena CF (eds) Understanding invasive species in the Galápagos Islands. Springer, Berlin, pp 95-139

Connett L, Guézou A, Herrera HW, Carrión V, Parker PG, Deem SL (2016) Gizzard contents of the smooth-billed ani Crotophaga ani in Santa Cruz, Galápagos Islands, Ecuador. Galápagos Res 68:43-48

Cooke SC, Haskell LE, van Rees CB, Fessl B (2019) A review of the introduced smooth-billed ani Crotophaga ani in Galápagos. Biol Conserv 229:38-49

Fessl B, Tebbich S (2002) Philornis downsi-a recently discovered parasite on the Galápagos archipelago_a threat for Darwin's finches? Ibis 144:445-451

Fessl B, Heimpel GE, Causton CE (2018) Invasion of an avian nest parasite, Philornis downsi, to the Galápagos Islands: colonization history, adaptations to novel ecosystems, and conservation challenges. Springer, Berlin, pp 213-266

Guerrero AM, Tye A (2011) Native and introduced birds of Galápagos as dispersers of native and introduced plants. Ornitol Neotrop 22:207-217

HerpMapper (2019) HerpMapper-a Global Herp Atlas and Data Hub. Iowa, USA. https://www.herpmapper.org. Accessed 01 Feb 2019

Izurieta A, Delgado B, Moity N et al (2018) A collaboratively derived environmental research agenda for Galápagos. Pac Conserv Biol 24:168-177

Jara ME (1995) Aspectos ecológico distribución y abundancia del garrapatero en el sur de la isla Isabela, Galápagos. Thesis, Pontificia Universidad Católica del Ecuador

Jara ME, de Vries T (1995) Distribución y abundancia del Garrapatero Crotophaga ani en las Islas Galápagos, Ecuador. Revista de la Pontificia Universidad Católica del Ecuador 23:121-169

Jiménez-Uzcátegui G, Zabala-Albizua J (2008) Status of introduced vertebrates in Galápagos. Galápagos Rep 2006-2007:136-141

Jiménez-Uzcátegui G, Márquez C, Snell HL (2017) CDF checklist of Galápagos reptiles-FCD Lista de especies de Reptiles Galápagos. In: Bungartz F, Herrera H, Jaramillo P, Tirado N, Jiménez-Uzcátegui G, Ruiz D, Guézou A, Ziemmeck F (eds) Charles Darwin Foundation Galápagos Species Checklist - Lista de Especies de Galápagos de la Fundación Charles Darwin. Charles Darwin Foundation, Puerto Ayora, Galápagos. https://darwinfoundation.org/ datazone/checklists/vertebrates/reptilia/. Accessed 14 Nov 2017

Koster F (1971) Nesting behaviour of Ani, Crotophaga ani. Bonn Zool Beitr 22:4-27

Lasso TL (1997) Ecologia e impacto de la avispa introducida (Polistes versicolor, Vespidae-Hymenoptera) en las Islas Floreana y Santa Cruz, Galápagos Ecuador. Thesis, Universidad Central del Ecuador, Quito

Leary S, Underwood W, Anthony R et al (2013) AVMA guidelines for the Euthanasia of animals: 2013 edition

Llerena A (2012) Measuring impact and optimizing control of the invasive smooth-billed ani in Galápagos, Ecuador. Report, GNPS, GCREG, CDF and GC, Puerto Ayora, Galápagos, Ecuador

McMullen CK (1989) The Galápagos carpenter bee, just how important is it? Noticias de Galápagos 48:16-18

Mieles A, Bersosa F (2005) Composición de la dieta de Scinax quinquefasciatus (Fowler, 1913) (Anura: Hylidae). Isla 
Isabela, Laguna de las Diablas. Technical report, Charles Darwin Foundation

Parent C (2000) Life cycle and ecological impact of Polistes versicolor, an introduced predatory wasp on the Galápagos Islands, Ecuador. Thesis, Carleton University

Phillips RB, Wiedenfeld DA, Snell HL (2012) Current status of alien vertebrates in the Galápagos Islands: invasion history, distribution, and potential impacts. Biol Invasions 14:461-480

Roque-Álbelo L, Landry B (2018) CDF Checklist of Galápagos Butterflies and Moths-FCD Lista de especies de Mariposas y polillas Galápagos. In: Bungartz F, Herrera H, Jaramillo P, Tirado N, Jiménez-Uzcátegui G, Ruiz D, Guézou A, Ziemmeck F (eds) Charles Darwin Foundation Galápagos Species Checklist-Lista de Especies de Galápagos de la Fundación Charles Darwin. Charles Darwin Foundation/Fundación Charles Darwin, Puerto Ayora, Galápagos: https:// darwinfoundation.org/datazone/checklists/terrestrialinvertebrates/lepidoptera/. Accessed 17 Jan 2018

Rosenberg DK (1987) Nuevas amenazas para las aves nativas. Report, Charles Darwin Foundation, Puerto Ayora, Galápagos, Ecuador

Rosenberg DK, Wilson MH, Cruz F (1990) The distribution and abundance of the smooth-billed ani Crotophaga ani (L.) in the Galápagos Islands, Ecuador. Biol Conserv 51:113-123

Sandler B (1988a) Summary and conclusions of activities concerning smooth billed ani in Galápagos. Report, Charles Darwin Foundation, Puerto Ayora, Galápagos, Ecuador

Sandler B (1988b) History and present status of the introduced smooth-billed ani Crotophaga ani in Galápagos. Charles Darwin Research Station Annual Report 1988-1989. Charles Darwin Foundation, Puerto Ayora, Galápagos, Ecuador

Soria Carvajal M (2006) Avian seed dispersers of the invasive Rubus niveus (Rosaceae) in Santa Cruz Island, Galápagos, Ecuador. Thesis, University of Missouri-St. Louis
Sutherland WJ, Pullin AS, Dolman PM, Knight TM (2004) The need for evidence-based conservation. Trends Ecol Evol 19:305-308

Tapia W, Patry M, Snell H, Carrión V (2000) Estado actual de los vertebrados introducidos a las islas Galápagos. Informe Galápagos 1999-2000

Torres-Carvajal O, Tapia W (2011) First record of the common house gecko Hemidactylus frenatus Schlegel, 1836 and distribution extension of Phyllodactylus reissii Peters, 1862 in the Galápagos. Check List 7:470

Traveset A, Heleno R, Chamorro S, Vargas P, McMullen CK, Castro-Urgal R, Nogales M, Herrera HW, Olesen JM (2013) Invaders of pollination networks in the Galápagos Islands: emergence of novel communities. Proc R Soc B 280:20123040

Traveset A, Chamorro S, Olesen JM, Heleno R (2015) Space, time and aliens: charting the dynamic structure of Galápagos pollination networks. AoB Plants 7:plv068

Vintimilla JE (2005) Estudios para el control y disminución de ranas: Scinax quinquefasciatus, con impactos mínimos en los humedales de Isabela Sur (Islas Galápagos). Thesis, Universidad de Cuenca

Wiedenfeld DA (2005) Censo de cucuves de Floreana 2005. Report, Charles Darwin Foundation, Puerto Ayora, Galápagos, Ecuador

Young CG (1929) A contribution to the ornithology of the coastland of British Guiana. Part II. Ibis 71:1-38

Zaher H, Yánez-Muñoz MH, Rodrigues MT, Graboski R, Machado FA, Altamirano-Benavides M, Bonatto SL, Grazziotin FG (2018) Origin and hidden diversity within the poorly known Galápagos snake radiation (Serpentes: Dipsadidae). Syst Biodivers 16:614-642

Publisher's Note Springer Nature remains neutral with regard to jurisdictional claims in published maps and institutional affiliations. 